\title{
After Quarantine: The Future of Screendance
}

\author{
Moderator: Omari 'Motion' Carter, London Contemporary Dance School \\ Sandra Maduoma, University of East London \\ Antoine Marc, Independent artist \\ Vilma Tihilä, Independent artist \\ Alice Underwood, Independent artist \\ James Williams, Independent artist
}

This roundtable was presented on 13 March 2021 as part of the symposium connected to this special issue, This Is Where We Dance Now: Covid-19 and the New and Next in Dance Onscreen. It has been edited for clarity and length. The video of the full roundtable conversation and $\mathrm{Q}+\mathrm{A}$ is viewable at: https://doi.org/10.18061/ijsd.v12i0.8347

ROUNDTABLE

AFTER QUARANTINE: THE FUTURE OF SCREENDANCE

With Sandra Maduoma, Antoine

Marc, Vilma Tihilä, Alice

Underwood, and James Williams

Moderated by

Omari 'Motion' Carter

Saturday, March 13

9am LA / 12pm NYC /

$5 \mathrm{pm}$ London /

4am (14/3) Sydney

\section{THIS IS WHERE WE DANCE NOW} COVID-19 AND THE NEW AND NEXT IN DANCE ONSCREEN

(1) THE OHIO STATÉ UNIVERSITY
GLOBAL ARTS + HUMANITIES DISCOVERY THEME

Photo by Elena Benthaus, used with permission. Design by Regina Harlig. 
Keywords: Covid-19, screendance, film, dance film, future, translation, image, collaboration, education, online, digital, access

Omari 'Motion' Carter: I'm so happy to have you guys here and to hear what you have to say. This is a big question - what is the future of screendance? We're looking at being oracles in a sense. Please introduce yourselves, and let us know where in the world you are.

Sandra Maduoma: I am Sandra. I am based in London, UK where I study urban dance practice at the University of East London. I'm actually taking screendance as one of my modules at the moment. You know in the post-pandemic world, we don't know what's going to happen. However, I do believe that screendance is actually taking over the dance industry. People who have never had to learn about editing and filming have had to learn by force. We've had to learn to use Zoom, and all of these different platforms, and it's just going to keep growing.

There's no way it's going to go back to just seeing dance in a theater. More people in my generation are taking a lot more interest. I wasn't really interested in screendance until I started studying it, and learning, and seeing that it's a whole 'nother language, seeing that actually there's so much more you can do with screendance-not only with choreography, but with the different angles of the different shots, the different editing. So I really feel like it's just going to keep growing and this generation is going to build up and help people outside of screendance to really believe and respect dance and art in themselves.

Screendance is going to represent not only different types of dancers, but different types of artists and genres as well. At the moment, I see more contemporary screendances, but I really feel that urban styles are going to come into it a lot more, especially crossing over into Black Lives Matter and other issues as people continue to use screendance as a way to voice their ideas and opinions. I'm really excited to see what the future holds. I definitely believe that it's just going to keep growing and growing and growing.

Omari: Thank you so much for that. Wicked.

Antoine Marc: My name is Antoine Marc. I'm a film director and choreographer based in London. And what a special year it has been. It's true that there's something very special about screendance, and precisely as Sandra was saying, we were able to see how much it has expanded already just after one year of this challenge. And there are different possibilities, as well as ramifications, with how things have changed. I'm thinking of dance film festivals. I always loved to travel, but the reality was thatwhether in terms of time or resources - it was often difficult to actually go to all of them, and it was not something that everyone was able to do. This and last year so many 
dance film festivals moved onto the digital space. And that means so many people across the globe were instantly connected and able to network and share ideas, and even share different ways of seeing screendance throughout the world. More room has been created for discussion-just like is happening right now. It's been quite amazing in the sense of giving more people accessibility to a platform to really experience different points of view of how screendance is created and the impact that it had, and will have, across the world.

In terms of specifics, last year I directed an interactive dance film called (Re)United. You select the character/story that you want to experience, and that little change integrates audience participation. We have had some amazing feedback, so I think in the future, it is something that we will implement much further and more often, because it creates that instant co-connection and personalizes the experience. I also recently shot an XR (extended reality) dance film. The challenge was to actually understand the technology better to see its future application. XR has become kind of mainstream thanks to Disney's The Mandalorian, but immersing a performer into a virtual world is something that dance film can integrate as the technology is becoming more accessible.

To conclude, we can already see the different possibilities for how dance film can be the bridge that connects the performer and the audience at home, as well as the creators. This is kind of an exciting time to be creating stuff.

Omari: The future is closer than you think! The more we learn about the technology available to us in this current age, the more we realize it was there already, before we found it ourselves.

Vilma Tihilä: My name is Vilma Tihilä, and I'm a dance filmmaker from Finland. I thought I'd start with a few questions:

- What is behind the words?

- What is before the words?

- What is it that one can only know by feeling it or experiencing it?

- What is it which cannot be explained with words, or what is the vocabulary for a language with no words?

These are a few of the questions I often return to in my work. And for me, the potential and the challenge in dance filmmaking is to find the ideas and techniques that deal with these questions in practice. For me, the key approach in this practice is poetics. Dance filming, its physical and visual and aural languages, has a poetic approach that offers radical and self-reflective, fluid and innovative strategies to address questions in meaning-making, communication, and storytelling. And I think this is the power 
of screendance to challenge the thinking and doing in the fields of cinema, dance, media arts, visual arts, and so on.

Thinking of everyday life and the visual era we are living in now has really made me think how the imagery we are creating and absorbing affects our being and behavior. And in my opinion, we need more soft, accepting, and listening visuals. We need to learn how to ask with images, rather than to possess with images. Deconstructing, questioning, and challenging norms through the poetry of movement and image in dance film links with feminist issues and intersectional perspectives. Asking not only what-but more importantly, how-is the key. Having an ongoing conversation about meanings, working methods, hierarchies and roles, responsibilities, and objectives is important. The way of working becomes a part of the final film. And in communicating all of this we need, of course, language. Words. Meanings. Visions. Action. And this brings me back to where I started: What is behind the words? What is before the words? What is it that one can only know by feeling it or experiencing it? What is it which cannot be explained with words?

Omari: I remember once at the Frame Rush festival an artist called Cléophée Moser said the words we use-the idea that the camera "captures," it "shoots"—we use really harsh words to describe how we get our material.

Alice Underwood: I'm Alice. I'm a filmmaker and I work predominantly with dance artists and in the creative arts sector. Pre-pandemic, I was filming a lot of social content for live shows-trailers and short documentaries looking into creation processes. Over the past year obviously things have changed quite a bit, and it has opened up some collaborations on really great screendance specific works. I've gotten more involved in ideas and planning shoots, and I'm loving the type of screendance works that I'm doing at the moment. I'm looking forward to getting back into the studio and to working with live works again, but I'm also looking forward to seeing where the screendance path takes me.

What I'm noticing is that there may be a bit more scope to interlink live work and film. There's a huge amount of live work which is standalone-which you go to see at the theater-and I think it's the same with screendance. There's some great standalone screendance works but there's not necessarily much connection between the two. There's a good opportunity to combine the two within one process, which I know is already happening, but I think there's definitely more scope for this. I don't mean altering live work, but using the ideas and themes and materials from a live show and creating a screendance work that complements it. I don't mean replicating a live show, so it wouldn't be the case that once you've seen one you don't need to see the other, but rather that one supports the other as another outcome from a creation process that can be used in different ways. We all know films can reach a wider audience and create better accessibility, which crucial. So you could see the film and it makes you interested 
to see the live show, and vice versa. They would each be new experiences in themselves and used for different purposes.

Screendance has always been developing, but this last year has just rocketed it into the forefront. I think as people have delved into the filming side of things, their eyes have been opened to the possibilities that the camera can lend, and the other things that can be shown through its lens. A whole new array of visual ideas can be created that aren't necessarily doable in a live show situation, but would really complement a live show well. And I like the idea that there could bean umbrella of different outcomes from one initial idea that stretches out to create different experiences and reaches different audiences in different ways. I want to push screendance and see what can be created.

Omari: That makes perfect sense. Even when we make single screen works, we always create multiple outputs. The filmmakers out there aren't just making one Apple ProRes version for the cinema screen, we're also making a H.264 for YouTube, and a 1 $\mathrm{x} 1$ aspect ratio for Instagram. So it's good to think about what types of screens we're putting these things on, and how we're integrating them to make multiple livesmultiple souls — of this idea for it to have longevity beyond just a single screen.

James Williams: I'm James Williams. I'm an ex-dancer and circus performer, now fully transitioned into cinematography. I split my time between dance film/screendance and the commercial world. I try and balance the two out and give myself a little bit of scope. I've been preparing what I wanted to say and the question of what is the future of screendance post-Covid was something I've really had to think about. I had to really search for what I thought the root of that question actually was and, I think I've maybe come down to something that's a little bit of an uninhibited answer. What do I think the future of screen dance is post-Covid? It's the same as it was prior to the pandemic. I don't see the pandemic as a catalystfor something that's changed the future of screendance, but instead it's just worked as an accelerant, spring-boarding us 5-10 years ahead of where we would have been without a pandemic.

If we look at where we were in 2019 on the eve of the pandemic, we see every single live performance art weighing the utilization of digital integration in some way-either in their development process, in their presentation, or just in their marketing outreach like we were just talking about with Alice. For the future of screendance, I wanted it to be something that is widely acceptable and an invaluable creative option for choreographers and dance companies considered the beginning of the choreography development, and is weighed as an option against live presentation. So the screen presentation would sit along things like outdoor festivals, site-specific work, or the traditional proscenium arch. All of those things are equally valid options. When the pandemic shut everything down, it forced the industry to look at the screen as the valid option. I don't think it changed where we were going, it just accelerated us exponentially to get there. 
Where I get a little bit more predictive, I think that dance is about to face kind of a new birth into the public eye, much like it did when TV and network competitions like Britain's Got Talent jump-started the influx of young dancers about 15 years ago. More screendance means more representations of the dancing body are shared digitally than ever before. How will dancers decide to represent themselves and their art form with this newfound position of digital exploration and exposure?

Omari: These are all head-nod provocations. I want to keep thinking about the future. What kind of work do we want to see? Is there something we need more of? Is there something we need to invent? We've tapped on this but I wonder if we can expand a bit.

Antoine: Well like Alice was saying, new ways of integrating dance film into a complex organism of dance performance or exhibition so that it can be explored and experienced in a different way.

Alice: Something l'd love to see more of is animation. I've seen a few films recently which have had brilliant animation and actual proper art in there. I love that.

Omari: Oh yeah, my favorite dance moment in animation is the scene in Dumbo, "Elephants on Parade," when Dumbo gets drunk and hallucinates. If you haven't seen that in a while, watch that scene again and let it blow your mind.

James: What I would like to see more of is dance film thought about as a film, produced as a film, presented as a film. At the moment, it's dance film made by dancers, produced by dancers, developed by dancers, and then presented as a film. So there's a big disconnect. It actually isn't that collaborative of a process, it's dancers dictating how to make a film with no real input from filmmakers, and no real education about film. So I would like to see more of dance film collaboratively developed as a film.

Sandra: To me, it seems that there can almost be a line-l'm the filmmaker and you're the dancer. What if it integrates more so that everyone gets each other's understanding? Then it's more of a collaboration than when you just go up to the line. Let's actually cross over the line and try and understand each other's backgrounds.

Vilma: I think one of the questions I always ask is how to make the translation? If we come from a dance background and think in the logic of the stage and choreography, how to make the translation into images? To recreate the effect of a big jump on stage might mean going to close-up in film. You have to go into the details to get the feeling of the physical awesomeness. It's the translation process.

Antoine: It often comes down to education. Dance film now is much more accessible to everyone, but it still requires specific tools and understanding of filmmaking to create something that has integrity in both in dance and film. So that would include creating a storyboard, having a pre-shoot, even editing your entire film. 
Omari: We talked about education. We're seeing lots of screendance undergraduate and postgraduate courses. Vilma studied with me on the Master's in screendance, Sandra is doing the course now, James has taught with me in the past. But I always think to myself, well, what do screendancers need to know? It's such a different process to dance for theater than it is for film. How do we train for film? A lot of those courses are on dance courses, not on film courses. But at the moment, now that we can't get into the studio, I find that I'm really just teaching film, and I can't get them to embody the camera. How do you think these courses can contribute to the future of what we make as artists?

James: I think really teaching what collaboration is would be huge, because it took me a long time. I came from dance and then I transitioned out to film, and it took me years of doing my own films and building up small projects with clients before I actually understood how to work as part of a team. And I think that came from being a dancer, where the choreographer runs the show right from the beginning. If you're putting a show on in a theater, the choreographer does all the rehearsals, they probably have applied for the funding right from the get-go. It's not probably until 3 days before the show that they even meet with a lighting technician in the theater. That's not a collaboration. So you have to unlearn that, and I think that's the educational part of it. Because film is just a team. Without the right team, the film doesn't get made right.

Vilma: I couldn't agree more. I really want to learn how to break out from doing every part of the work in each part of the production. Bringing in more brains, and discussing things, and developing the whole film - the whole idea, each scene, each charactertogether with the group can just bring everything further. And then one person is not going to be dead from doing the job of 12 or 20 people. I would also add teamwork or collaboration into screendance education.

Alice: With the question of what is screendance education doing and is it helpful, I got into filmmaking through a screendance module in my undergraduate dance course. We didn't know what we were doing, it was a big test-but it propelled me into film. I had wanted to be a dancer, I diverted and went into film, and now l've connected the two and it's brilliant. But as you're learning, you're not going through a big film course and learning all the intricacies and everything you're meant to know. Once the module's done, you're teaching yourself. Having people by your side who you can lean on and collaborate with is so important.

Sandra: Coming from a dance background, learning about film hands-on has been very helpful. When I collaborate in the future, I'll be able to understand more. I also think it comes from humbling yourself. It's not just about you. It's about humbling yourself and trusting that other people have good ideas as well. Compromise doesn't mean you're weak. It actually means you're stronger, and that different people's ideas can create a whole new world, a whole new language. 
Omari: You never do anything on your own, you know?

\section{Audience $\mathrm{Q}+\mathrm{A}$}

Simon Ellis: How do you all think screendance collaboration is distinctive from other forms of collaboration in and outside of film?

James: I think in the current process, the collaboration is minimal. It's not a collaboration between two entities: a choreographer and a director, or a choreographer and a cinematographer, for example. It's not two people joining to make a single piece of art, it's the choreographer hiring the filmmaker to make their vision. There are obviously also some wonderful collaborations that I've had the privilege of being involved in.

Omari: I hear that James, but we mold the mode to move our moving images. We can change it. Even seeing Katrina McPherson on stage with the camera and interacting with the performers changed my whole life! It opened up a new way of thinking about how we practice.

Yerin Lee: Maybe understanding the camera's view and getting used to being in front of the camera, and communicating it as well? Because South Korea doesn't have any Screendance or Dancefilm courses yet, so when I tried to collaborate with Korean dancers, they said that they have difficulties being in front of the camera.

Vilma: Right now I'm doing a dance film and we've found a way to work together with the camera. The expression in the camera can be very specific. If you're really in a closeup, making a tiny shift with your eyes might tell too much. Or if you're a tiny person in a huge wide shot, it might require way more expression and movement than what you'd do onstage. It's just also doing, and seeing, and trying, and doing again, and bringing the camera into the rehearsals.

Antoine: It's really about understanding those details that are possible with the different framings, and to really work with the performers so that the performance is specific to what is being shot. And to build the emotion for the entire storyline not just for a specific moment in the choreography, so that when you shoot it, the emotion corresponds to what it should be within the film. That's why the camera should be brought in as early as possible, so that performers can get comfortable with an entire crew looking at them and the pressure of hearing "action" and suddenly everyone's relying on them.

Omari: It's such a different process, so how do we train for film?

Douglas Rosenberg: The stage/camera or dance/camera dialectic anchors screendance to an arcane set of rules. What is the intent of the project? What is the desired outcome or mode of reception and why am I undertaking this project? 
Collaboration exists on a spectrum and there are no absolutes about what collaboration looks like. Much of what I am hearing frames film as in service to dance. That will lead to a very particular outcome and close the door to other possibilities. The festival model has enforced a kind of platform determinism: short, single offering from numerous authors. It is a limitation that becomes the motivating factor for makers and thus becomes a methodology.

Clare Schweitzer: There's been a lot of mention of accessibility. People are able to see more dance film, but I still think a lot needs to be done as far as who we are seeing onscreen and who actually has the tools to create work or engage in collaboration. These times have exposed a lot of inequities and barriers to access. San Francisco Dance Film Festival went online, and the films we select don't have to conform to cinematic settings so we are seeing films that are shot on an iPhone. The priority of the festival has really shifted toward films that people can't see anywhere else. Now is an opportunity to ask what are we not seeing? who are we not seeing? And can we share that perspective and encourage more creation from that perspective as well?

Alice: I love the fact that smaller productions, even productions that have no budgets, have been shown in online film festivals. People have different money to play with, but it comes down to what can be created. It's not all about the gear. It's not all about the money. What can be created with what you've got? And I think some of the films that have come out with very little support have been incredible, and I love them.

Omari: Everyone's got the tools now, they've all got phones.

Antoine: Most phones now have a pro version of video. As long as you can shoot, you can learn so much about lighting, about contrast, and about the basics of filmmaking.

Gitta Wigro: I was thinking about this idea of the future that we're building this on, and something that I worry about in the future is that I don't think screendance / dance film has very much of its own infrastructure. A lot of what we do is based on other infrastructures, especially dance and universities. And both of those, particularly in the UK, are going to get a massive hit from Brexit. Some of the infrastructure that we use and rely on is going to go away, I think. How do we keep things going and find other resources to make it brighter and more beautiful and more weird and all different?

Harmony Bench: I really hear this infrastructure question-it's about sustainability in times of precarity. What practices can exist when the supporting infrastructures are under threat?

Claudia Kappenberg: Crossing into other art forms and their institutions is the challenge-but they are keen! We have so much to offer right now.

Katrina McPherson: Do people think that the 'cult of the individual' that is perhaps encouraged by social media etc. works against true collaborative processes? Also, do festivals perhaps work against a different way of working by still insist on credits being 
such as 'director,' choreographer,' 'dancer' and find it hard to accept more nonhierarchical processes?

Vilma: I think this question links quite a lot with what Gitta was saying. These crediting different people, it's a tradition from the field of film. And I do find it very hard to find non-hierarchical strategies. It's not so hard when we are working, but when it's finished and presented, how to communicate the work in the dance field or the film field.

Claudia Kappenberg: Besides crediting at festivals there is also the reliance on open submissions and very little curating of programs around issues, practices, histories in the art form. This has been an issue for a long time and there is little change-and I wonder why?

Clare Schweitzer: At least from a US perspective, I feel the role of the festival tends to be locally focused with the intention of stimulating production of Screendance work in local communities. Histories of Screendance are certainly valuable, but are by no means comprehensive and rife with erasure.

Hannah Fischer: I do think it is important to discuss the edges and inner scaffolding of the field, to name it, otherwise intention and vision tend to be amorphous in my experience.

Omari: I heard in a talk recently that the edges are the new center. And what's happening is that the people who have now become the new center don't necessarily know how to orientate themselves in the center because maybe we've never been there before. And so let's keep working. Thank you to Sandra, Vilma, James, Antoine, Alice. Let's keep it moving. We mold the modes to move our moving images.

\section{Biographies}

Omari 'Motion' Carter is a screendance practitioner and lecturer based in London and, for the past decade, has been choreographing and performing for music videos, film, television and theatre. He is the founder and creative director of award-winning screendance production company, The Motion Dance Collective, associate lecturer in screendance at London Contemporary Dance School (LCDS), Lincoln University and University of East London, and is graduate of the world's first MA in Screendance at LCDS.

Email:info@motiondancecollective.com

Website: https://www.motiondancecollective.com/ 
Sandra Maduoma is 19 years old and based in London, UK. She originally grew up in Essex but moved into the big city when she began her journey in the BA (Hons) Dance: Urban Practice at the University of East London. There are three thing she holds close to her heart and that is her love for Christ, Family and Dance! From a young age she fell in love with dance and its variety of skills and techniques. Since then she's trained with choreographers such as Botis Seva, Kloe Dean and Seeta Patel. Sandra was introduced to screendance through lecturers Omari Carter MA and Dr. Claudia Brazzale in 2020 and is currently studying on the Hip Hop and the Choreography of Digital Activism module this year. Since then it has sparked her interest of learning more about the field in its entirety. She says, "Dance on screen has been a knowledgeable journey for me already. The transfer from stage to screen creates a whole new language and process. I am hoping to keep growing, and impact lives through the two mediums merging together."

Website: https://www.instagram.com/25sandraaa/

Antoine Marc: Multi Award Winning director and choreographer working on live shows and films to bring cutting edge Technology and logistics consultancy from production's development to its completion.

In 2015, received the Van Gogh Award by the Amsterdam Film Festival Jury and the Beoordelen van Comité.

In 2016, awarded the Cannes Global Film Awards at the Red Carpet and Fashion event for Best Dance Film.

In 2017, honoured by Limelight Award for best Visual content.

In 2019, was awarded the ARFF award for Best experimental film.

Additionally, he was nominated for Best Choreographer at the International

Achievement Recognition Award.

Through 18 years of creative experience, Antoine had the privilege to work with established brands and organizations such as BBC, Royal Opera House, Olympic Ceremonies, Canadian Opera Company, Ferrari, Virgin Active, Sony.

Engaged in both live performances and films, developed work that prides itself by being rich in collaborations between Creatives and Performers.

His credits includes Israr Award ceremony, Award winning Fashion film Paroha, Swatch Global launch, David Guetta live performance, Volvo National Launch, Olympics Opening Ceremony, Award winning film Descent.

In collaboration with film production, Arts \& Movements Ltd, produce films and technological performances.

Email: antoinemarc@mail.com

Website: https://antoinemarc.com/

Vilma Tihilä (b. 1991) is Finnish film director specializing in dance film. She combines contemporary dance and physical theatre to visual storytelling and poetry of film in her work. In her current dance film productions Tihilä explores the influence of different cultures in the stories told through the movement and the camera; the process of 
adapting a stage piece into a film; and surrealistic experiences in one's reality. Working at the edges of different artistic disciplines and techniques, Tihilä asks: How an image can touch? How physical experience translates into moving image? How to visually communicate what is after, before, or behind the words? Tihilä holds Master of Arts in Screendance from London Contemporary Dance School and a degree in contemporary dance from Turku Conservatory. She has also studied physical cinema at Stockholm Academy of Dramatic Arts. Tihilä's films have been screened at various festivals internationally including Loikka Dance Film Festival in Finland, Quinzena de Dança de Almada in Portugal, F-O-R-M Festival in Canada, and Video-poetry Festival in Argentina, among others.

Email: tihilavilma@gmail.com

Website: www.vilmatihila.com

Alice Underwood transitioned into filmmaking after initially training in dance, thus developing a unique style due to her specialist understanding of movement. For the past 7 years she has been making films with a range of choreographers, dance companies, and artists across the creative arts industry. She has collaborated with renowned organisations and festivals, such as East London Dance, Dance Umbrella, Akademi, Gandini Juggling, Crying Out Loud and Far From The Norm, making films that increase supporter following and attract new audiences to dance and the performing arts.

Email: alicekju26@gmail.com

Website: https://www.aliceunderwoodfilms.com/

James Williams started working as a Cinematographer after a career as a professional dancer and circus artist. His connection to the Performing Arts scene meant he could combine these experiences and has, as a result, found a firm foothold in the Screendance genre. Aside from his work in the world of dance James has worked on a range of projects from documentaries to commercials, and alongside household names including GAP, BMW and Skoda.

Email: jwcinematographer@hotmail.com

Website: https://www.jwcinematographer.co.uk/

\section{Resources in order of mention}

(Re)United. Dir. Antoine Marc. Perf. Kristina Alleyne and Sadé Alleyne. Prod. Alleyne Dance. 2021. https://www.alleynedance.com/reunited/

The Mandalorian. Disney Media Distribution. www.disneyplus.com/mandalorian/ 
Dumbo. "Pink Elephants on Parade." Dir. Samuel Armstrong. Prod. Walt Disney

Productions. 1941. https://www.youtube.com/watch?v=jcZUPDMXzJ8

Bordwell, David. Poetics of Cinema. New York: Routledge, 2008.

Ceiling. Dir. Katherine Helen Fisher and Govind Rae. Prod. Safety Third Productions. 2016. https://vimeo.com/192860832

Regards Hybrides. http://regardshybrides.com/en/

Harlig, Alexandra. "Commercials as Dance Videos." YouTube playlist. Accessed 19 May 2021. https://www.youtube.com/playlist?list=PLmllprdZcMY6EXeLHBXYCNExZpPSDXkK 